\title{
Human Platelet Lysate Promotes Proliferation but Fails to Maintain Chondrogenic Markers of Chondrocytes
}

\author{
(Lisat Platelet Manusia Mempromosikan Proliferasi tetapi Gagal Mengekalkan Penanda Kondrogen dalam Kondrosit)
}

Prana Hardinata bin Budi Harto, MuHammad Hanif Bin MaHmud, Aisya Hanim Binti OthMAn,

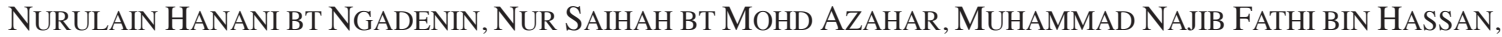
Nor Hamdan Mohd Yahaya, Rizal Abdul Rani, Chooi Fun LeOnG, Min Hwei NG \& Jia Xian LAW*

\begin{abstract}
Traditionally, foetal bovine serum (FBS) is used as a serum supplement for stem cell expansion in vitro. However, it is associated with xenoimmunisation and the transmission of animal pathogens, which may cause harm to stem cell recipients. As a safer alternative, human platelet lysate (HPL) has been introduced for propagating stem cells. Chondrocytes are expanded in vitro for cartilage repair via autologous chondrocyte implantation (ACI). In this study, we compare the efficacy of HPL prepared from expired platelet concentrates with that of FBSfor promoting the proliferation and maintenance of the chondrogenic markers of primary human chondrocytes expanded in vitro. Chondrocytes were cultured in F12:Dulbecco's modified Eagle's medium (DMEM) supplemented with 5\% HPL, 10\% HPL and 10\% FBS. The cell morphology, viability and growth rate were examined from passage $1(P 1)$ to $P 3$. RNA was isolated from $P 3$ cells for quantitative polymerase chain reaction $(q P C R)$ to determine the gene expression level of the chondrogenic, dedifferentiation and hypertrophic markers. HPL promoted chondrocyte proliferation without compromising cell viability. In addition, the chondrocytes cultured with HPL were smaller. However, HPL failed to maintain the chondrogenic markers, except SOX 9 (SRY-box transcription factor 9), which was upregulated, but not significantly. Nonetheless, HPL also suppressed the expression of type X collagen (Col X), a chondrocyte hypertrophic marker. In summary, we demonstrate the benefits of HPL supplementation in human chondrocyte culture, where it enhances cell proliferation and suppresses chondrocyte hypertrophy. In the future, HPL can be used for the large-scale expansion of chondrocytes for ACI.
\end{abstract}

Keywords: Autologous chondrocyte implantation; cartilage; chondrocyte; osteoarthritis; platelet lysate

ABSTRAK

Secara tradisinya, serum anak lembu (FBS) digunakan untuk pengkulturan sel in vitro. Namun demikian, FBS dikaitkan dengan penolakan oleh sistem imun dan penularan patogen haiwan yang berkemungkinan membawa kemudaratan kepada penerima sel induk. Lisat platelet manusia (HPL) telah diperkenalkan sebagai alternatif yang lebih selamat untuk pengkulturan sel. Sel kondrosit telah dikultur secara in vitro untuk merawat rawan yang rosak melalui teknik implantasi kondrosit autologus (ACI). Pada kajian ini, kami membandingkan keberkesanan HPL yang disediakan daripada platelet pekat tamat tempoh dan FBS dalam merangsang proliferasi dan mengekalkan penanda kondrogenik sel kondrosit manusia yang dikulturkan secara in vitro. Sel kondrosit dikultur dalam medium F12:DMEM yang ditambah dengan 5\% HPL, 10\% HPL dan 10\% FBS. Morfologi, kadar kehidupan dan kadar pertumbuhan sel daripada P1 hingga P3 dikenal pasti. RNA dipencil daripada sel pada P3 untuk qPCR untuk menentukan ekspresi gen penanda-penanda kondrogenik, penyahbezaan dan hipertrofi. Hasil kajian mendapati HPL merangsang proliferasi sel kondrosit tanpa memkompromikan kadar kehidupan sel. Selain itu, sel kondrosit yang dikultur dengan HPL menunjukkan saiz yang lebih kecil. Namun demikian, HPL gagal mengekalkan penanda-penanda kondrogenik kecuali sOX 9 yang meningkat secara tidak signifikan. Pada masa yang sama, HPL juga didapati menurunkan ekspresi kolagen jenis X (Col X), satu penanda hipertrofi sel kondrosit. Secara kesimpulan, kajian kami menunjukkan HPL bermanfaat untuk pengkulturan sel kondrosit dengan merangsang proliferasi dan menghalang perubahan hipertrofi sel kondrosit. Pada masa yang akan datang, HPL boleh digunakan untuk pengkulturan sel kondrosit berskala besar.

Kata kunci: Implantasi kondrosit autologus; lisat platelet; osteoarthritis; rawan; sel kondrosit

\section{INTRODUCTION}

Osteoarthritis (OA) is a common joint disease worldwide. The articular cartilage defects in OA are associated with pain and joint dysfunction, which severely affect patient quality of life (Hamoud et al. 2012; Ude et al.2018). Apart from the elderly, $\mathrm{OA}$ is becoming more common in youths, especially those active in sports (Amoako \& Pujalte 2014). Replacing arthritic cartilage with an artificial prosthesis has long been the treatment modality for severe OA (Ahmad et al. 2015). The usual treatment for older patients aged 
$>60$ years is total knee replacement. However, physicians have found it challenging to treat younger patients aged $<50$ years because the prostheses have a limited lifespan (Stiebel et al. 2014).

Autologous chondrocyte implantation (ACI) was introduced in 1987 as the first cell-based approach for treating articular cartilage defects (Viste et al. 2012). In brief, the technique involves isolating and culturing autologous chondrocytes from cartilage biopsy collected from the non-weight-bearing area of the joint and later implanting it in the damaged area under a periosteal cover. The periosteum provides a waterproof layer for covering the transplanted chondrocytes, as well as growth factors and mesenchymal stem cells that enhance cartilage regeneration (Peterso et al. 2010). ACI is an effective and durable choice for treating large, full-thickness cartilage defects of the knee joint, sustaining clinical and functional improvements for up to 20 years after the implantation (Peterson et al. 2010). Mistry et al. (2017) proved that ACI is not only cost-effective but also leads to long-term improvement. Scientists and clinicians have come to a consensus that ACI should be performed as early as possible and as the first surgical intervention to yield the best results (Sykes et al. 2018). All these findings suggest that ACI has the potential to be the definitive treatment for $\mathrm{OA}$ in the near future.

One of the crucial steps in $\mathrm{ACI}$ is the in vitro expansion of chondrocytes, which should be able to yield the needed cell number in the shortest time without compromising cell quality. However, dedifferentiation, which refers to the process whereby chondrocytes lose their chondrogenic markers and chondrocyte phenotype, is very common in cells expanded in vitro (Ma et al. 2013). Dedifferentiated chondrocytes lose their rounded morphology and have reduced secretion of cartilage extracellular matrix (ECM) such as type II collagen (Col II) and aggrecan (ACAN) (Schulze-Tanzil 2009). Hence, dedifferentiation reduces the ability of culture-expanded chondrocytes to regrow functional cartilage upon transplantation.

Foetal bovine serum (FBS) has long been used as a serum supplement for in vitro chondrocyte expansion. FBS is produced from blood drawn from bovine foetuses (Hemeda et al. 2014). It is widely used in cell culture because it is easy to produce, rich in paracrine factors that support cell proliferation and is suitable for a variety of cells (Yao \& Asayama 2017). Despite its numerous advantages, its usage also carries a few disadvantages that render it not ideal for culturing cells meant for clinical use. The disadvantages of FBS include imprecisely defined content as well as the presence of animal pathogens and proteins that may cause immune activation in transplant recipients (Cimino et al. 2017).

In vitro cell expansion using human platelet lysate (HPL) was first introduced in the 1980s (Doucet et al. 2005). HPL can be produced from platelet concentrates through a simple freeze-thawing method. Similar to FBS, HPL is also rich in growth factors that support cell proliferation. The usage of HPL in cell culture lowers the risk of immune rejection and infection in transplant recipients. However, HPL presents a transmission risk of blood-borne diseases, as do other blood products used for transfusion. Typically, HPL is prepared from a large pool of platelet concentrates from multiple donors to minimize lot-to-lot variation (Hemeda et al. 2014).

The aim of the present study was to determine the growth rate and chondrogenic markers of primary human chondrocytes cultured with HPL prepared from expired platelet concentrates. The cell morphology, viability and growth rate were examined. In addition, the expression of chondrogenic, dedifferentiation and hypertrophic markers of cells cultured with the different growth supplements was quantified using quantitative polymerase chain reaction (qPCR).

\section{MATERIALS AND METHODS}

\section{ETHICAL APPROVAL}

The study was conducted with approval from Universiti Kebangsaan Malaysia Research Ethics Committee (Reference number: UKM PPI/111/8/JEP-2018-100).

\section{PREPARATION OF HPL}

Expired platelet concentrates were obtained from the Blood Bank Unit of Universiti Kebangsaan Malaysia Medical Centre (UKMMC) and stored at $-80^{\circ} \mathrm{C}$ before processing. To prepare HPL, 3-5 bags of expired platelet concentrates were thawed in a $37^{\circ} \mathrm{C}$ water bath and pooled. The freezthaw cycle was repeated to ensure lysis of all platelets. Subsequently, the supernatant was collected and filtered through a 100- $\mu$ m cell strainer (Corning, USA) after 15 min centrifugation at $4500 \mathrm{~g}$. Heparin (final concentration, 4 $\mathrm{IU} / \mathrm{mL}$ ) was added to prevent clotting, and the processed HPL was stored at $-20^{\circ} \mathrm{C}$ until used.

\section{CHONDROCYTE CULTURE}

Human chondrocytes were isolated from the cartilage of consenting donors who had undergone total knee replacement at UKMMC. The tissue was minced and treated with type II collagenase (Worthington, USA) to dislodge the chondrocytes. The chondrocytes were cultured in 6 -well tissue culture plates in equal volumes of Ham's F12 medium (Gibco, USA) and Dulbecco's modified Eagle's medium (Gibco) supplemented with $10 \%$ FBS (Sigma, USA), 200 mM L-glutamine (Gibco), 100 U/mL penicillin (Gibco), $100 \mu \mathrm{g} / \mathrm{mL}$ streptomycin (Gibco), 0.25 $\mu \mathrm{g} / \mathrm{mL}$ amphotericin B (Gibco) and $50 \mathrm{mg} / \mathrm{mL}$ ascorbic acid (Sigma). The culture was maintained in a $5 \% \mathrm{CO}_{2}$ incubator at $37^{\circ} \mathrm{C}$. The culture medium was changed three times a week.

\section{CELL MORPHOLOGY, VIABILITY AND PROLIFERATION}

The morphological features of the chondrocytes cultured with HPL and FBS were examined every 3 days by capturing 
images under an inverted light microscope (Leica, Germany). Cultured chondrocytes were grown to $80 \%$ confluence before being released from the culture plate using $0.05 \%$ trypsin-EDTA (Sigma) to quantify the cells and determine their viability using a haemocytometer and trypan blue dye. Viability was determined using the following formula:

$$
\text { Viability }=\frac{\text { Total live cells }}{\text { Total live cells }+ \text { Total dead cells }} \times 100 \%
$$

The chondrocytes were expanded three times from passage 1 (P1) to P3 with similar cell seeding densities and culture conditions. The cell growth rate, i.e. population doubling time (PDT), was calculated using the following formula:

$$
P D T=\frac{t \log 2}{\log N_{2}-\log N_{1}}
$$

where $t$ denotes the time in culture (hours); $N_{2}$ denotes the cell number at the end of the passage; and $N_{1}$ denotes the cell number seeded at the beginning of the passage.

\section{TOTAL RNA EXTRACTION}

Total RNA of the cultured chondrocytes was extracted using Direct-zol ${ }^{\mathrm{TM}}$ RNA MiniPrep (Zymo Research, USA) according to the manufacturer's instructions. The extracted RNA yield and purity were confirmed using a spectrophotometer. Total RNA was stored at $-80^{\circ} \mathrm{C}$ after extraction.

\section{REAL-TIME PCR}

Real-time PCR was performed to quantitatively analyse the gene expression of chondrogenic (Col II, ACAN, fibromodulin [Fmod], SOX 9), dedifferentiation (Col I) and hypertrophy $(\mathrm{Col} \mathrm{X})$ markers of $\mathrm{P} 3$ chondrocytes. Primer 3 software and the GenBank database were used to design the primers (Table 1). The extracted RNA was converted to complementary DNA (cDNA) using iScript ${ }^{\mathrm{TM}}$ Reverse Transcription (RT) Supermix (Bio-Rad, USA). Reactions were run using iTaq ${ }^{\mathrm{TM}}$ Universal SYBR ${ }^{\circledR}$ Green Supermix (Bio-Rad) and the Rotor-Gene Q RT-PCR cycler (Qiagen, Germany) for 40 cycles. This series of cycles was followed by melt curve analysis to examine the reaction specificity. The expression level of each targeted gene was normalized to that of glyceraldehyde-3-phosphate dehydrogenase (GAPDH), and the chondrocyte differentiation index (the ratio of Col II mRNA expression to that of Col I, Col II/ Col I index) was calculated.

\section{STATISTICAL ANALYSIS}

All data are presented as the mean \pm standard error of mean and analysed using GraphPad Prism 7 (GraphPad Software, USA) with $\mathrm{n}=6$ for cell growth and $\mathrm{n}=3$ for RTPCR. Statistical significance was calculated using one-way analysis of variance (ANOVA) followed by Tukey's multiple comparison test, where $\mathrm{p}<0.05$ was considered significant.

\section{RESULTS}

\section{MORPHOLOGY OF CULTURED CHONDROCYTES}

The primary human chondrocytes cultured with HPL had poor cell attachment at $\mathrm{P} 0$. Thus, we cultured the cells with FBS at P0 and then with HPL starting from P1. The cells were cultured in medium supplemented with 5\% HPL, 10\% HPL and $10 \%$ FBS until confluent, and then subcultured and grown again to confluence until P3. The cells cultured with FBS and HPL displayed fibroblast-like morphology at all passages. However, the cells cultured with HPL were smaller, longer and narrower compared to that cultured with FBS (Figure 1). In addition, the cells cultured with HPL

\begin{tabular}{|c|c|c|c|}
\hline Gene & Primer sequence (5'-3') & Product size (bp) & Accession number \\
\hline $\begin{array}{l}\text { Glyceraldehyde-3-phosphate } \\
\text { dehydrogenase (GAPDH) }\end{array}$ & $\begin{array}{l}\text { F - caatgaccecttcattgacc } \\
\text { R - ttgattttggagggatctcg }\end{array}$ & 160 & NM_002046.5 \\
\hline Type II collagen (Col II) & $\begin{array}{l}\text { F -gggagtaatgcaaggaccaa } \\
\text { R -atcatcaccaggctttccag }\end{array}$ & 175 & NM_001844.4 \\
\hline Aggrecan (ACAN) & $\begin{array}{l}\text { F -acagctggggacattagtgg } \\
R \text {-gtggaatgcagaggtggttt }\end{array}$ & 189 & NM_001135.3 \\
\hline Fibromodulin (Fmod) & $\begin{array}{l}\text { F - cctcaagtacctgccettcg } \\
\text { R - tcactggtgatctggttgec }\end{array}$ & 144 & NM_002023.4 \\
\hline SOX 9 & $\begin{array}{l}\text { F -tacgactacaccgaccacca } \\
\text { R -tcaaggtcgagtgagctgtg }\end{array}$ & 194 & NM_000346.3 \\
\hline Type I collagen (Col I) & $\begin{array}{l}\text { F -gtgctaaaggtgccaatggt } \\
R \text {-accaggttcaccgctgttac }\end{array}$ & 128 & NM_000088.3 \\
\hline Type X collagen ( $\mathrm{Col} \mathrm{X})$ & $\begin{array}{l}\mathrm{F} \text { - ccagcacgcagaatccatct } \\
\mathrm{R} \text {-tatgcctgtgggcattggt }\end{array}$ & 119 & NM_000493.3 \\
\hline
\end{tabular}

TABLE 1. Primer sequences of targeted gene 


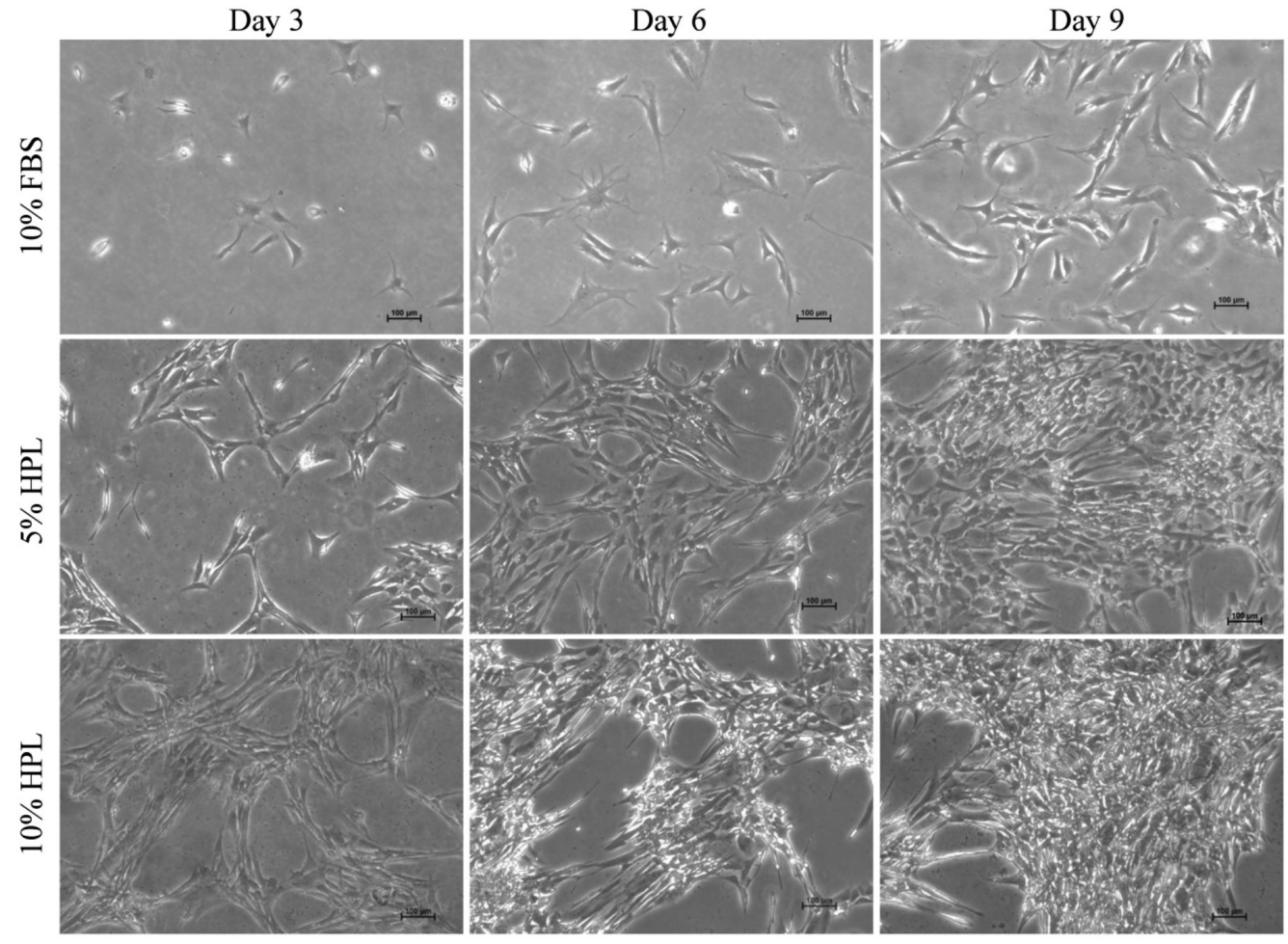

FIGURE 1. Images of passage 3 primary human chondrocytes cultured with FBS and HPL. The chondrocytes have similar fibroblastic morphology from P1 to P3. Nonetheless, the chondrocytes cultured with HPL were smaller in size, narrower and more elongated compared to those cultured with FBS

clustered together and overlapped when reaching higher confluence at all passages.

\section{VIABILITY OF CULTURED CHONDROCYTES}

No significant differences were detected in the viability of cells cultured with the different supplements at P1 and P2, whereby all groups showed viability of $>90 \%$. At P3, the cell viability of the FBS group was slightly lower $(88.02$ $\pm 2.91 \%)$ and was significantly different compared to chondrocytes cultured with 10\% HPL (Figure 2(a)).

\section{GROWTH RATE OF CULTURED CHONDROCYTES}

From P1 to P3, the viable cell yield when the cultures were $80 \%$ confluent was approximately $2.0-4$.6-fold higher in the HPL groups compared the FBS group. There were significant differences between the 10\% HPL group and $10 \%$ FBS group at all passages and between the 5\% HPL group and 10\% FBS group at P1. Even though the viable cell yield was approximately 1.7 -fold and 1.8 -fold higher in the $10 \%$ HPL group compared to the 5\% HPL group at P2 and $\mathrm{P} 3$, respectively, the differences were not statistically significant (Figure 2(b)). At all passages, the HPL groups had significantly shorter PDT and significantly higher population doubling number compared to the FBS group. In addition, there was a significant difference in the number of population doubling between the 10\% HPL and 5\% HPL groups at P3 (Figure 2(c) and 2(d)).

\section{GENE EXPRESSION OF CULTURED CHONDROCYTES}

The expression of chondrogenic markers, except SOX 9, was lower in the HPL groups compared to the FBS group (Figure 3). Significant differences were found only for $\mathrm{Col}$ II and ACAN expression between the HPL groups and FBS group. No differences were detected for Fmod and sox 9. The expression of Col I, a chondrocyte dedifferentiation marker, was significantly lower in the HPL groups compared to the FBS group (Figure 4). Furthermore, the expression of $\mathrm{Col} \mathrm{X}$, a chondrocyte hypertrophic marker, was also significantly lower in the HPL groups compared to the FBS group (Figure 5). None of the supplements could maintain the chondrogenic markers of the cultured chondrocytes, as the $\mathrm{Col} \mathrm{II} / \mathrm{Col} \mathrm{I}$ index was very low for all groups (Figure 6).

\section{DISCUSSION}

$\mathrm{ACI}$ has been a targeted therapeutic approach for OA patients, as it has shown encouraging results for repairing full-thickness cartilage defects (Mistry et al. 2017; Peterson et al. 2010). ACI safety and efficacy are very much dependent on the functionality of the cultured chondrocytes. The biggest challenge in chondrocyte expansion is the loss of the chondrocyte phenotype during serial monolayer culture in a process known as dedifferentiation. Dedifferentiation alters chondrocyte morphology and metabolism (Hamada et al. 2013). HPL has 


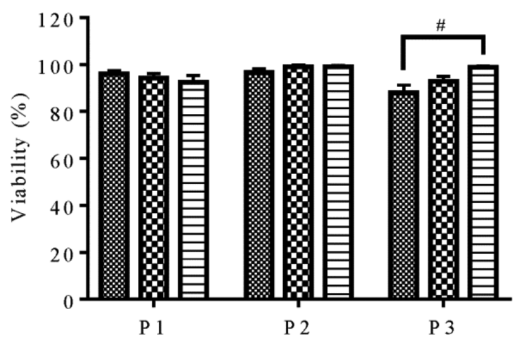

$\mathrm{a}$
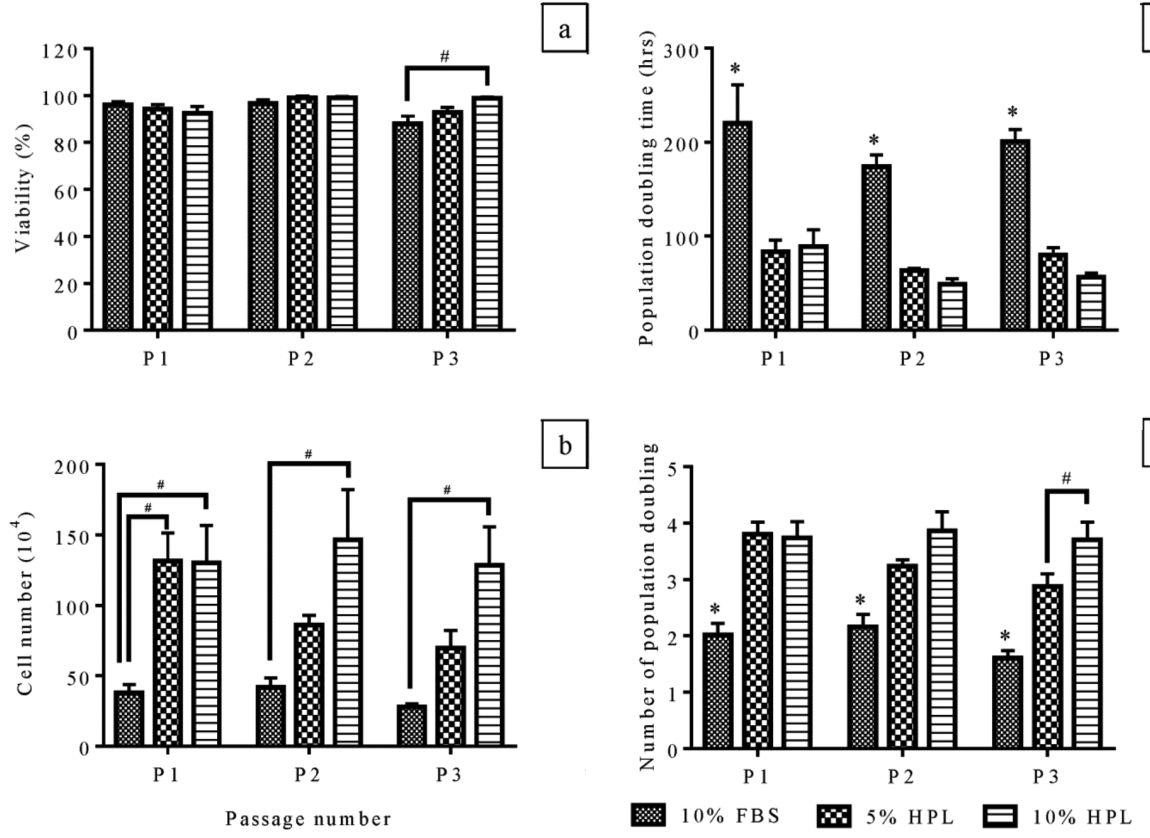

FIGURE 2. Viability and growth rate of primary human chondrocytes cultured with FBS and HPL (a) The cell viability was above $90 \%$ except for the P3 cells cultured with $10 \%$ FBS, (b) HPL increased the viable cell yield at all passages, (c) HPL shortened the population doubling time at all passages, and (d) HPL increased the number of population doubling at all passages $(\mathrm{n}=6) .^{*}, \mathrm{p}<0.05$ between groups. ${ }^{*}, \mathrm{p}<0.05$ compared to the $5 \%$ HPL and $10 \%$ HPL groups
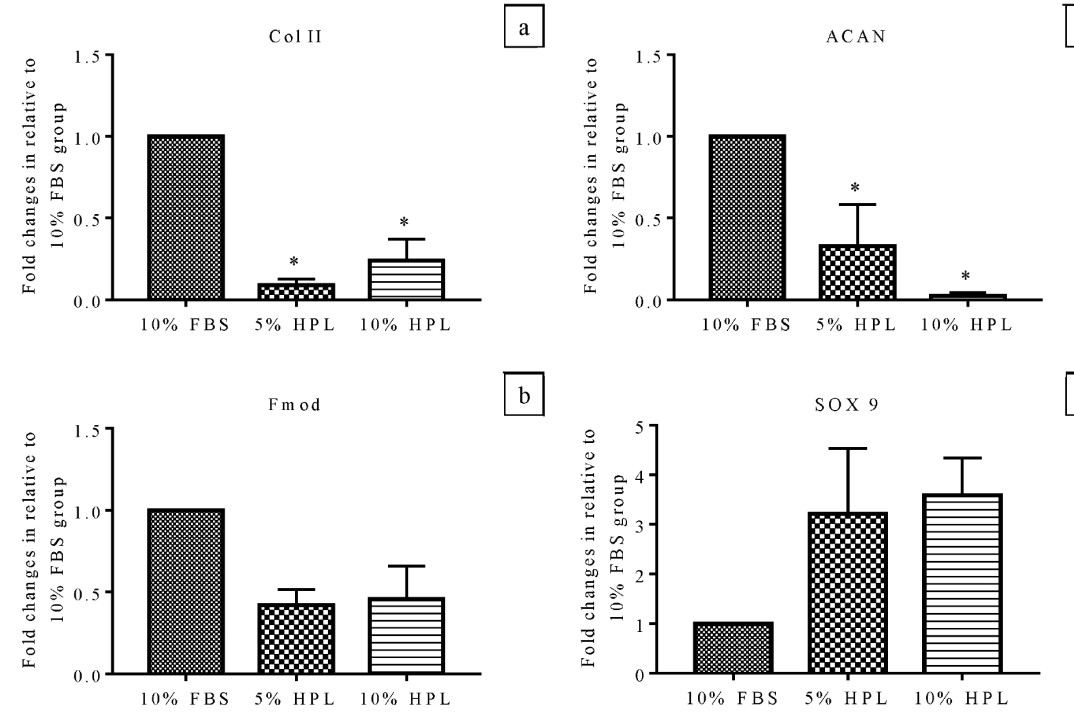

$\mathrm{b}$

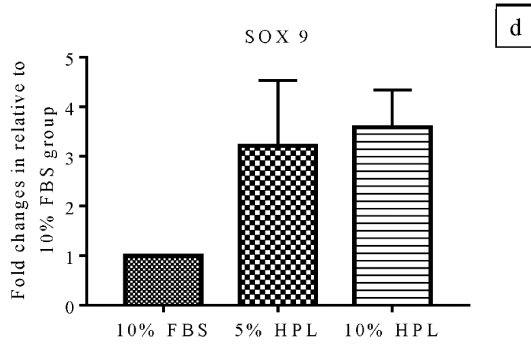

FIGURE 3. Gene expressions of chondrogenic markers. The expression of Col II (a), Fmod (b) and ACAN (c) were lower for the 5\% HPL and 10\% HPL groups compared to the 10\% FBS group. The HPL groups have higher expression of SOX 9 (d) compared to the FBS group $(n=3)$. *, p $<0.05$ compared to the $10 \%$ FBS group

been regarded as a safer alternative to FBS for the expansion of cells targeted for therapeutic use. Thus, in the present study, we investigated the proliferation and chondrogenic markers of primary human chondrocytes cultured with HPL prepared from expired platelet concentrates.

Here, there were few differences in the morphology of chondrocytes cultured with HPL and FBS. With both supplements, the cells appeared flattened and elongated.
Pereira et al. (2013) and Sykes et al. (2018) reported a similar observation. They found that the phenotype of monolayer chondrocytes cultured with HPL changed from polygonal to spindle-shaped. Nonetheless, we found that the chondrocytes cultured with HPL, especially with $10 \%$ HPL, were slightly smaller, longer and narrower. Furthermore, the chondrocytes cultured with HPL tended to cluster together and overlap when reaching higher 


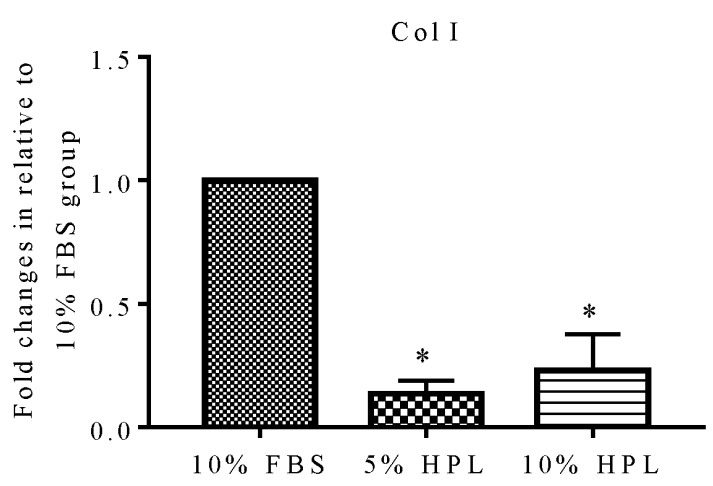

FIGURE 4. The expression of Col I, a chondrocyte dedifferentiation marker, was lower in the HPL groups compared to the FBS group $(\mathrm{n}=3)$. *, $\mathrm{p}<0.05$ compared to the $10 \%$ FBS group

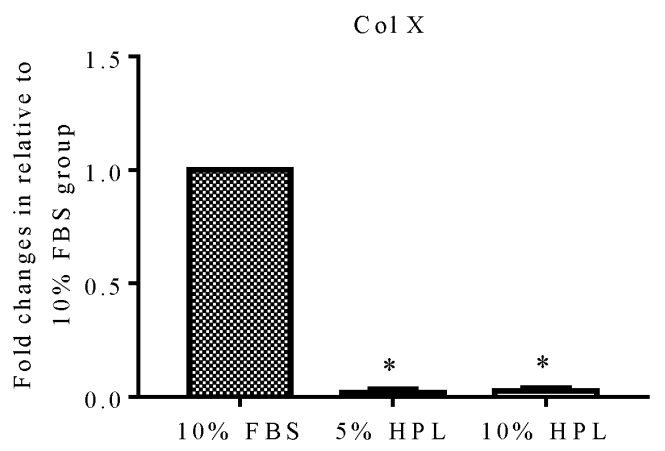

FIGURE 5. The expression of Col X, a chondrocyte hypertrophic marker, was lower in the HPL groups compared to the FBS group $(\mathrm{n}=3) .^{*}, \mathrm{p}<0.05$ compared to the $10 \%$ FBS group

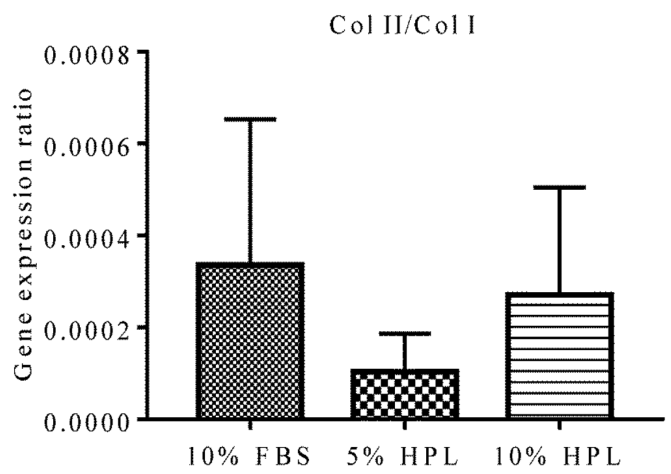

FIGURE 6. The gene expression ratio of $\mathrm{Col} \mathrm{II} / \mathrm{Col}$ I was very low for all groups indicating that both supplements failed to maintain the chondrogenic phenotype of cultured chondrocytes $(n=3)$

confluence. These observations are likely to be the reason for the higher cell yield in the HPL groups compared to the FBS group at similar cell confluency from P1 to P3. Cultures supplemented with HPL could yield up to 4-fold more cells. Several researchers have reported the ability of HPL to promote the proliferation of cultured chondrocytes
(Hildner et al. 2015; Sykes et al. 2018). Interestingly, the cell clustering and overlapping in culture did not affect the cell viability, which was $>90 \%$. In addition, we found that the growth-promoting capability of 5\% HPL was reduced in response to higher cell passages. However, the chondrocyte growth rate was maintained in the $10 \%$ HPL group from $\mathrm{P} 1$ to P3. Thus, even though 5\% HPL supplementation is effective for promoting chondrocyte proliferation at lower passages, $10 \%$ HPL supplementation might be needed for chondrocytes at higher passages.

Chondrocytes secrete a myriad of ECM proteins to maintain cartilage tissue. Thus, we performed qPCR to quantitate the gene expression of ECM proteins to examine the characteristics of the cultured chondrocytes. The expression of major ECM proteins of articular cartilage, i.e. Col II, ACAN and Fmod, were decreased in the HPL groups compared to the FBS group. These findings indicate that HPL failed to maintain the chondrocyte phenotype. In contrast, SOX 9 expression was higher in the HPL groups. Similarly, Hildner et al. (2015) also reported higher SOX 9 expression in adipose-derived mesenchymal stem cells cultured with HPL compared to that cultured with FBS. SOX 9 is a transcriptional factor that regulates chondrocyte proliferation, cartilage formation and the suppression of chondrocyte hypertrophic changes (Sykes et al. 2018). Dedifferentiated chondrocytes with higher Sox 9 expression are more responsive to chondrogenic signals and produce more cartilage ECM (Hardingham et al. 2006; Li et al. 2004; Tew et al. 2005). We postulate that the chondrocytes cultured with HPL maintained higher SOX 9 expression due to the presence of a higher concentration of growth factors in the supplement. In the future, the growth factor responsible should be identified. Our RT-PCR results support the findings of Pereira et al. (2013), who reported that chondrocytes cultured with FBS lost the potential to redifferentiate faster than that cultured with HPL (Pereira et al. 2013). Similarly, Hildner et al. (2013) showed that chondrocytes expanded with HPL have higher Col II and GAG protein production when the cells were cultured in 3D (Hildner et al. 2015). In contrast, Kaps et al. (2002) and Sykes et al. (2018) found that HPL-expanded chondrocytes cultured in 3D secreted less GAG protein. The discrepancy in the results from these studies and ours might be due to the differences in HPL, as every study uses HPL prepared using different methods.

Higher Col I expression has long been used as an indicator of chondrocyte dedifferentiation. Col I is a fibrilforming collagen found in abundance in many tissues, including the cornea, dermis and tendons, but not articular cartilage (Law et al 2017a, 2017b, 2016). Here, Col I expression was lower in the HPL groups compared to the FBS group. Nonetheless, the $\mathrm{Col}$ II/Col I index was very low for all groups, showing that neither HPL nor FBS could prevent the dedifferentiation of monolayer chondrocytes.

$\mathrm{Col} \mathrm{X}$ is highly expressed in hypertrophic chondrocytes found in OA cartilage (Luo et al. 2017). Approximately $45 \%$ of collagens produced by hypertrophic chondrocytes are Col X (Shen 2005). The present results show that Col 
$\mathrm{X}$ expression was lower in the HPL groups compared to the FBS group. Col $\mathrm{X}$ is increased in chondrocytes in serial monolayer culture (Lin et al. 2008). These findings suggest that HPL supplementation might be able to prevent hypertrophic changes of cultured chondrocytes.

The limitation of this study is that our in-house HPL did not perform well in supporting the attachment of freshly isolated P0 chondrocytes. We were unable to establish primary chondrocyte culture for cartilage samples, with lower cell yield upon isolation using HPL supplementation. Thus, we used FBS to culture the P0 chondrocytes and used HPL only from P1 onwards. We suggest that in the future, a suitable coating substrate should be used to enhance chondrocyte attachment when HPL supplementation is used at $\mathrm{P} 0$.

\section{CONCLUSION}

Even though it failed to maintain the chondrogenic markers, HPL appears to be a better alternative to FBS for culturing chondrocytes, as it allows more efficient expansion and prevents hypertrophic changes of the cells.

\section{ACKNOWLEDGEMENTS}

This work was supported by the PPUKM Fundamental Grant (FF-2018-110) from the Faculty of Medicine, Universiti Kebangsaan Malaysia Medical Centre and Research University Grant (GGPM-2017-050) from Universiti Kebangsaan Malaysia. The authors declare that there are no conflicts of interest.

\section{REFERENCES}

Ahmad, S., Gantenbein, B., Evangelopoulos, D.S., Schär, M.O., Schwienbacher, S., Kohlhof, H. \& Kohl, S. 2015. Arthroplasty-current strategies for the management of knee osteoarthritis. Swiss Medical Weekly 145: w14096.

Amoako, A.O. \& Pujalte, G.G.A. 2014. Osteoarthritis in young, active, and athletic individuals. Clinical Medicine Insights. Arthritis and Musculoskeletal Disorders 7: 27-32.

Cimino, M., Gonçalves, R.M., Barrias, C.C. \& Martins, M.C.L. 2017. Xeno-free strategies for safe human mesenchymal stem/stromal cell expansion: Supplements and coatings. Stem Cells International 2017: 6597815.

Doucet, C., Ernou, I., Zhang, Y., Llense, J., Begot, L., Holy, X. \& Lataillade, J. 2005. Platelet lysates promote mesenchymal stem cell expansion: A safety substitute for animal serum in cell-based therapy applications. Journal of Cellular Physiology 205(2): 228-236.

Hamada, T., Sakai, T., Hiraiwa, H., Nakashima, M., Ono, Y., Mitsuyama, H. \& Ishiguro, N. 2013. Surface markers and gene expression to characterize the differentiation of monolayer expanded human articular chondrocytes. Nagoya Journal of Medical Science 75(1-2): 101-111.

Hamoud, A.F., Bin Mohamad Yahya, N.H., Hui, C.C., Bin Saim, A. \& Bt Hj Idrus, R. 2012. The potential of intro-articular injection of chondrogenic-induced bone marrow stem cells to retard the progression of osteoarthritis in a sheep model. Experimental Gerontology 47: 458-564.
Hardingham, T.E., Oldershaw, R.A.\& Tew, S.R. 2006. Cartilage, SOX9 and Notch signals in chondrogenesis. Journal of Anatomy 209(4): 469-480.

Hemeda, H., Giebel, B. \& Wagner, W. 2014. Evaluation of human platelet lysate versus fetal bovine serum for culture of mesenchymal stromal cells. Cytotherapy 16(2): 170-180.

Hildner, F., Eder, M.J., Hofer, K., Aberl, J., Redl, H., van Griensven, M., Gabriel, C. \& Peterbaue-Scherb, A. 2015. Human platelet lysate successfully promotes proliferation and subsequent chondrogenic differentiation of adiposederived stem cells: A comparison with articular chondrocytes. Journal of Tissue Engineering and Regenerative Medicine 9(7): 808-818.

Kaps, C., Loch, A., Haisch, A., Smolian, H., Burmester, G.R., Häupl, T. \& Sittinger, M. 2002. Human platelet supernatant promotes proliferation but not differentiation of articular chondrocytes. Medical and Biological Engineering and Computing 40(4): 485-490.

Law, J.X., Chowdhury, S.R., Aminuddin, B.S. \& Ruszymah, B.H.I. 2017a. Role of plasma-derived fibrin on keratinocyte and fibroblast wound healing. Cell and Tissue Banking 18(4): 585-595.

Law, J.X., Liau, L.L., Saim, A., Yang, Y. \& Idrus, R. 2017b. Electrospun collagen nanofibers and their applications in skin tissue engineering. Tissue Engineering and Regenerative Medicine 14(6): 699-718.

Law, J.X., Musa, F., Ruszymah, B.H.I., El Haj, A.J. \& Yang, Y. 2016. A comparative study of skin cell activities in collagen and fibrin constructs. Medical Engineering and Physics 38(9): 854-861.

Li, Y., Tew, S.R., Russell, A.M., Gonzalez, K.R., Hardingham, T.E. \& Hawkins, R.E. 2004. Transduction of passaged human articular chondrocytes with adenoviral, retroviral, and lentiviral vectors and the effects of enhanced expression of SOX9. Tissue Engineering 10(3-4): 575-584.

Lin, Z., Fitzgerald, J.B., Xu , J., Willers, C., Wood, D., Grodzinsky, A.J. \& Zheng, M.H. 2008. Gene expression profiles of human chondrocytes during passaged monolayer cultivation. Journal of Orthopaedic Research 26(9): 1230-1237.

Luo, Y., Sinkeviciute, D., He, Y., Karsdal, M., Henrotin, Y., Mobasheri, A., Önnerfjord, P. \& Bay-Jensen, A. 2017. The minor collagens in articular cartilage. Protein \& Cell 8(8): 560-572.

Ma, B., Leijten, J.C.H., Wu, L., Kip, M., van Blitterswijk, C.A., Post, J.N. \& Karperien, M. 2013. Gene expression profiling of dedifferentiated human articular chondrocytes in monolayer culture. Osteoarthritis and Cartilage 21(4): 599-603.

Mistry, H., Connock, M., Pink, J., Shyangdan, D., Clar, C., Royle, P., Court, R.A., Biant, L.C., Metcalfe, A. \& Waugh, N. 2017. Autologous chondrocyte implantation in the knee: Systematic review and economic evaluation. Health Technology Assessment 21(6): 1-294.

Pereira, R.C., Scaranari, M., Benelli, R., Strada, P., Reis, R.L., Cancedda, R.\& Gentili, C. 2013. Dual effect of platelet lysate on human articular cartilage: A maintenance of chondrogenic potential and a transient proinflammatory activity followed by an inflammation resolution. Tissue Engineering Part A 19(11-12): 1476-1488.

Peterson, L., Vasiliadis, H.S., Brittberg, M. \& Lindahl, A. 2010. Autologous chondrocyte implantation: A long-term follow-up. The American Journal of Sports Medicine 38(6): 1117-1124. 
Schulze-Tanzil, G. 2009. Activation and dedifferentiation of chondrocytes: Implications in cartilage injury and repair. Annals of Anatomy-Anatomischer Anzeiger 191(4): 325-338.

Shen, G. 2005. The role of type X collagen in facilitating and regulating endochondral ossification of articular cartilage. Orthodontics \& Craniofacial Research 8(1): 11-17.

Stiebel, M., Miller, L.E. \& Block, J.E. 2014. Post-traumatic knee osteoarthritis in the young patient: Therapeutic dilemmas and emerging technologies. Open Access Journal of Sports Medicine 5: 73-79.

Sykes, J.G., Kuiper, J.H., Richardson, J.B., Roberts, S., Wright, K.T. \& Kuiper, N.J. 2018. Impact of human platelet lysate on the expansion and chondrogenic capacity of cultured human chondrocytes for cartilage cell therapy. European Cells \& Materials 35: 255-267.

Tew, S.R., Li, Y., Pothacharoen, P., Tweats, L.M., Hawkins, R.E. \& Hardingham, T.E. 2005. Retroviral transduction with SOX9 enhances re-expression of the chondrocyte phenotype in passaged osteoarthritic human articular chondrocytes. Osteoarthritis and Cartilage 13(1): 80-89.

Ude, C.C., Seet, W.T., Sharen Aini, S., Aminuddin, B.S. \& Ruszymah, B.H.I. 2018. Shelf life evaluation of clinical grade chondrogenic induced aged adult stem cells for cartilage regeneration. Scientific Reports 8: 4345.

Viste, A.,Piperno, M., Desmarchelier, R., Grosclaude, S., Moyen, B. \& Fessy, M.H. 2012. Autologous chondrocyte implantation for traumatic full-thickness cartilage defects of the knee in 14 patients: 6-year functional outcomes. Orthopaedics \& Traumatology: Surgery \& Research 98(7): 737-743.

Yao, T. \& Asayama, Y. 2017. Animal-cell culture media: History, characteristics, and current issues. Reproductive Medicine and Biology 16(2): 99-117.
Prana Hardinata bin Budi Harto, Muhammad Hanif bin Mahmud, Aisya Hanim binti Othman, Nurulain Hanani bt Ngadenin, Nur Saihah bt Mohd Azahar, Muhammad Najib Fathi bin Hassan, Min Hwei Ng \& Jia Xian Law*

Tissue Engineering Centre, Faculty of Medicine Universiti Kebangsaan Malaysia Medical Centre Jalan Yaacob Latif, Bandar Tun Razak 56000 Cheras, Kuala Lumpur, Federal Territory Malaysia

Nor Hamdan Mohd Yahaya \& Rizal Abdul Rani Orthopaedic Department, Faculty of Medicine Universiti Kebangsaan Malaysia Medical Centre Jalan Yaacob Latif, Bandar Tun Razak 56000 Cheras, Kuala Lumpur, Federal Territory Malaysia

\section{Chooi Fun Leong}

Pathology Department, Faculty of Medicine

Universiti Kebangsaan Malaysia Medical Centre Jalan Yaacob Latif, Bandar Tun Razak 56000 Cheras, Kuala Lumpur, Federal Territory Malaysia

*Corresponding author; email: lawjx@ppukm.ukm.edu.my

Received: 7 January 2019

Accepted: 23 September 2019 